\title{
Macronutrientes em folhas diagnósticas do capim-tanzânia adubado com nitrogênio e cálcio
}

\author{
Cristiane Prezotto Silveira ${ }^{1}$, Francisco Antonio Monteiro ${ }^{2}$
}

\author{
1 Pós-graduanda em Solos e Nutrição de Plantas, ESALQ, Universidade de São Paulo, Caixa Postal 9, CEP:13418-900, Piracicaba, São Paulo, \\ Brasil. Bolsista FAPESP. \\ ${ }^{2}$ Departamento de Ciência do Solo, ESALQ, Universidade de São Paulo, Caixa Postal 9, CEP:13418-900, Piracicaba, São Paulo, Brasil. \\ Bolsista do CNPq.
}

RESUMO - Um experimento foi realizado em casa de vegetação com capim-tanzânia adubado com combinações de nitrogênio e de cálcio em solução nutritiva no período da primavera. O delineamento estatístico foi de blocos ao acaso, com quatro repetições, em esquema fatorial $5^{2}$ incompleto, com cinco doses de nitrogênio (2; 9; 16; 23 e $30 \mathrm{mmol} \mathrm{L}^{-1}$ ) e cinco de cálcio $(0,50 ; 1,75 ; 3,00 ; 4,25$ e 5,50 mmol L-1), resultando em 13 combinações nitrogênio:cálcio (mmol L-1): 2:0,50; 2:3,00; $2: 5,50 ; 9: 1,75 ; 9: 4,25 ; 16: 0,50 ; 16: 3,00 ; 16: 5,50 ; 23: 1,75 ; 23: 4,25 ; 30: 0,50 ; 30: 3,00$ e $30: 5,50$. Foram determinadas as concentrações dos macronutrientes nas lâminas de folhas recém-expandidas (diagnósticas) nos três cortes do capim. No primeiro corte das plantas, a dose de cálcio não interagiu com a de nitrogênio para qualquer característica nutricional, à exceção da concentração de enxofre nas folhas. A interação nitrogênio $\times$ cálcio foi significativa para as concentrações de cálcio e enxofre nas folhas no segundo e terceiro cortes do capim. As doses de nitrogênio, e não de cálcio, são determinantes das concentrações de nitrogênio, fósforo e potássio em folhas de capim-tanzânia. A concentração de cálcio no primeiro corte do capim depende apenas do suprimento desse nutriente. A concentração de magnésio no tecido vegetal decresce com o aumento no suprimento, tanto de nitrogênio quanto de cálcio. A redução da dose de cálcio para $40 \%$ daquela empregada na solução não prejudica os parâmetros nutricionais do capim-tanzânia, mesmo quando fornecidas elevadas doses de nitrogênio.

Palavras-chave: diagnose foliar, nutrição mineral, Panicum maximum, planta forrageira, solução nutritiva

\section{Macronutrients concentrations in Tanzania guineagrass diagnostic leaves supplied with nitrogen and calcium rates}

\begin{abstract}
An experiment under greenhouse conditions was carried out with Tanzania guineagrass supplied with combined rates of nitrogen and calcium in nutrient solutions during the spring season. A randomized block design was used, with four replicates, in an incomplete $5^{2}$ factorial scheme with five nitrogen rates (2; 9; 16; 23 e $30 \mathrm{mmol} \mathrm{L}^{-1}$ ) and five calcium rates $\left(0.50 ; 1.75 ; 3.00 ; 4.25\right.$ e $\left.5.50 \mathrm{mmol} \mathrm{L}^{-1}\right)$ resulting in 13 nitrogen:calcium combinations (mmol L $\left.{ }^{-1}\right): 2: 0.50 ; 2: 3.00$; $2: 5.50 ; 9: 1.75 ; 9: 4.25 ; 16: 0.50 ; 16: 3.00 ; 16: 5.50 ; 23: 1.75 ; 23: 4.25 ; 30: 0.50 ; 30: 3.00$ and 30:5.50. Macronutrient concentrations were determined in the two recently expanded leaf blades (diagnostic leaves) collected in the three harvests of Tanzania guineagrass. The results showed that, in the first harvest of the plants, calcium rates did not interact with nitrogen for any of the nutritional traits, except for sulphur concentration in the diagnostic leaves. The interaction nitrogen $\times$ calcium was significant for concentrations of calcium and sulphur in the diagnostic leaves at the second and third samplings of the grass. Nitrogen rates and, not calcium rates, are determinant for nitrogen, phosphorus, and potassium concentrations in the diagnostic leaves of Tanzania guineagrass. The concentration of calcium at the first harvest of the grass depends only on the supply of this nutrient. Concentration of magnesium in plant tissue decreases as nitrogen or calcium supply increases. Reduction of calcium to $40 \%$ of that one used in the nutrient solution does not reduce nutritional parameters of this grass, even with the supply of high nitrogen rate.
\end{abstract}

Key Words: forage plant, leaf diagnosis, mineral nutrition, nutrient solution, Panicum maximum

\section{Introdução}

A adequada disponibilidade de nutrientes é fundamental para o bom desenvolvimento de gramíneas forrageiras. Sabe-se que o fornecimento de nitrogênio
(N) é essencial após o desenvolvimento inicial da gramínea forrageira, quando passa a contribuir expressivamente para a produção de massa seca e a concentração desse nutriente na planta (Monteiro \& Werner, 1977). 
As informações relacionadas ao cálcio $(\mathrm{Ca})$ na nutrição mineral de gramíneas forrageiras são escassas, e a calagem excessiva, além de não aumentar a produção de massa do capim, pode provocar desbalanço nutricional nas plantas (Macedo, 2004).

Monteiro et al. (2001), avaliando a distribuição de nitrogênio na parte aérea do capim-tanzânia (Panicum maximum cv. Tanzânia), verificaram que as duas folhas de lâminas recém-expandidas acumularam mais nitrogênio (35 a 45\% do total na parte aérea das plantas) em comparação às folhas emergentes, às lâminas de folhas maduras e à fração colmos+bainhas. Manarin \& Monteiro (2002) constataram variação na concentração de nitrogênio no capim-mombaça (Panicum maximum cv. Mombaça) de 8,8 a 18,5 $\mathrm{g} \mathrm{kg}^{-1}$ e de 10,2 a 19,2 $\mathrm{g} \mathrm{kg}^{-1}$ nas lâminas de folhas recém-expandidas no primeiro e segundo cortes, respectivamente.

Avaliando o rendimento e diagnose foliar em Panicum maximum cultivares Aruana e Mombaça cultivados em Latossolo Vermelho-Amarelo, Colozza (1998) verificou que as doses de nitrogênio aumentaram a concentração de cálcio nas lâminas de folhas recém-expandidas. Santos Jr. (2005), em experimento com o capim-tanzânia sob pastejo na região dos Cerrados, encontrou a concentração máxima de 6,4 g kg-1 de Ca nas lâminas de folhas recémexpandidas no ciclo de pastejo de verão, enquanto, no ciclo de pastejo de outono, as concentrações de cálcio variaram linearmente de 4,1 a 4,4 $\mathrm{g} \mathrm{kg}^{-1}$.

Buscando contribuir para avanços na avaliação do estado nutricional do capim-tanzânia e, considerando a falta de resultados experimentais sobre o aspecto da nutrição em cálcio de gramíneas quando feita a adubação nitrogenada, avaliou-se a influência da aplicação de nitrogênio e cálcio e a relação entre as doses desses nutrientes nas concentrações de nitrogênio, fósforo, potássio, cálcio, magnésio e enxofre nas folhas diagnósticas (lâminas de folhas recém-expandidas) desse capim.

\section{Material e Métodos}

O experimento foi realizado em casa de vegetação localizada em Piracicaba, São Paulo, a espécie forrageira testada foi o capim-Tanzânia (Panicum maximum cv. Tanzânia), cultivado no período da primavera.

O capim foi submetido às combinações de cinco doses de nitrogênio $\left(2 ; 9 ; 16 ; 23 ; 30 \mathrm{mmol} \mathrm{L}^{-1}\right)$ com cinco de cálcio $\left(0,50 ; 1,75 ; 3,00 ; 4,25\right.$ e $\left.5,50 \mathrm{mmol} \mathrm{L}^{-1}\right)$, resultando em 13 combinações: 2-0,50; 2-3,00; 2-5,50; 9-1,75; 9-4,25; 16-0,50; 16-3,00; 16-5,50; 23-1,75; 23-4,25; 30-0,50; 30-3,00 e 30-5,50 mmol L $\mathrm{m}^{-1}$. Como fontes de nitrogênio e cálcio, foram empregadas soluções de $\mathrm{NH}_{4} \mathrm{NO}_{3}, \mathrm{KNO}_{3}, \mathrm{Ca}\left(\mathrm{NO}_{3}\right)_{2}$ e $\mathrm{CaCl}_{2}$.

Trabalhos como os de Abreu (1994) e Monteiro et al. (1995) evidenciam que a utilização conjunta de nitrato e amônio melhora o desempenho das plantas. Assim, cuidou-se de manter constante a proporção 65\% $\mathrm{NO}_{3}{ }^{-}$e $35 \% \mathrm{NH}_{4}{ }^{+}$na solução nutritiva. A concentração de $\mathrm{K}$ na solução nutritiva proposta por Sarruge (1975) é de $6 \mathrm{mmol} \mathrm{L}^{-1}$, e foi alterada para 8,0 $\mathrm{mmol} \mathrm{L}^{-1}$ em todas as combinações de nitrogênio e cálcio, em razão dos resultados apresentados por Mattos et al. (2002) para essa forrageira.

Empregou-se um estudo de superfície de resposta baseado em desenho experimental composto central modificado de um fatorial $5^{2}$ incompleto, de acordo com Littell \& Mott (1975), utilizando-se delineamento experimental de blocos ao acaso, com quatro repetições.

As mudas do capim-tanzânia foram formadas por meio da semeadura em bandejas plásticas contendo areia lavada em água corrente e em água desionizada. Após 14 dias da semeadura (início da primavera), foram transplantadas 15 mudas de aproximadamente $3 \mathrm{~cm}$ em cada vaso plástico com capacidade de 3,6 litros, contendo quartzo moído, também lavado em água corrente e em água desionizada.

Após o transplante das mudas, forneceu-se a cada vaso um litro de solução nutritiva diluída a 25\% das concentrações propostas, que permaneceram nos vasos por três dias até a troca para as soluções definitivas. As soluções nutritivas foram renovadas a cada 14 dias, circuladas quatro vezes ao dia para a aeração das raízes das plantas, drenadas no fim do dia e fornecidas toda manhã, quando se completou o volume de um litro com água desionizada. Desbastes periódicos das mudas foram realizados até permanecerem cinco plantas por vaso.

As plantas foram submetidas a três cortes, o primeiro aos 39 dias após o transplante, o segundo aos 30 dias após o primeiro corte e o terceiro aos 28 dias após o segundo corte. Em cada corte, a parte aérea das plantas foi separada em: a) folhas emergentes; b) lâminas de folhas recémexpandidas, ou seja, lâminas das duas folhas mais jovens totalmente expandidas, com lígula visível; c) lâminas das demais folhas maduras totalmente expandidas; e d) colmos + bainhas.

Todo o material vegetal colhido nos três períodos de crescimento foi seco em estufa com circulação forçada a $65^{\circ} \mathrm{C}$ até massa constante e, posteriormente, pesado e moído em moinho do tipo Willey.

As concentrações dos macronutrientes nas folhas e do nitrogênio e do cálcio nas raízes foram determinadas conforme metodologia descrita por Sarruge \& Haag (1974). Para o nitrogênio, empregaram-se a digestão sulfúrica e o 
método analítico semi-micro Kjeldahl e para os demais macronutrientes, a digestão nítrico-perclórica, seguida dos métodos analíticos de: colorimetria para o fósforo; espectrofotometria de absorção atômica para cálcio e magnésio; fotometria de chama para o potássio; e turbidimetria para o enxofre.

Os resultados foram submetidos às análises estatísticas utilizando-se o aplicativo Statistical Analysis System (SAS, 1999). Executou-se inicialmente o teste F e, para casos de significância da interação nitrogênio $\times$ cálcio, foram efetuadas análises de regressão polinomial (superfície de resposta) por meio do procedimento RSREG. Nos casos dessa interação não-significativa, utilizou-se o procedimento GLM para os estudos de regressão. Em todos os casos analisados adotou-se o nível de significância de 5\%.

\section{Resultados e Discussão}

A interação doses de nitrogênio $\times$ cálcio não foi significativa para a concentração de nitrogênio nas lâminas de folhas recém-expandidas do capim-tanzânia nos três cortes das plantas. Apenas as doses de nitrogênio tiveram efeito positivo e significativo, com ajuste dos resultados ao modelo de regressão linear, para as três colheitas realizadas nas plantas (Figura 1).

Maior concentração de nitrogênio no tecido vegetal do capim-mombaça com a aplicação de nitrogênio também foi relatada por Manarin \& Monteiro (2002), que verificaram nas lâminas de folhas recém-expandidas variação da concentração desse mineral de 8,8 a $18,5 \mathrm{~g} \mathrm{~kg}^{-1}$ no primeiro corte e de 10,2 a 19,2 $\mathrm{g} \mathrm{kg}^{-1}$ no segundo corte, dentro dos limites de 0 a 33,0 $\mathrm{mmol} \mathrm{L}^{-1}$. Também estimaram o nível crítico de nitrogênio de 16,0 a $16,5 \mathrm{~g} \mathrm{~kg}^{-1}$ para o capimmombaça, o que contrasta com os estimados por Volpe et al. (2008), que relataram concentração de nitrogênio de $20,0 \mathrm{~g} \mathrm{~kg}^{-1}$ nas folhas diagnósticas do capim-massai (Panicum maximum) como não limitante ao adequado crescimento desse capim.

Batista \& Monteiro (2007) observaram que doses de nitrogênio de 1,0 a 33,0 $\mathrm{mmol} \mathrm{L}^{-1}$ afetaram a concentração desse mineral nas lâminas de folhas recém-expandidas do capim-marandu (Brachiaria brizantha cv. Marandu), com oscilação de 16,0 a $31,0 \mathrm{~g} \mathrm{~kg}^{-1}$ na amostragem do primeiro corte e de 9,5 a $17,0 \mathrm{~g} \mathrm{~kg}^{-1}$ no segundo corte das plantas.

Em lâminas de folhas recém-expandidas do capimbraquiária (Brachiaria decumbens), Carvalho et al. (1991) constataram variação de 17,0 a 21,0 g kg$^{-1}$ na concentração de nitrogênio. No trabalho de Mattos \& Monteiro (2003), a concentração de nitrogênio nas lâminas de folhas
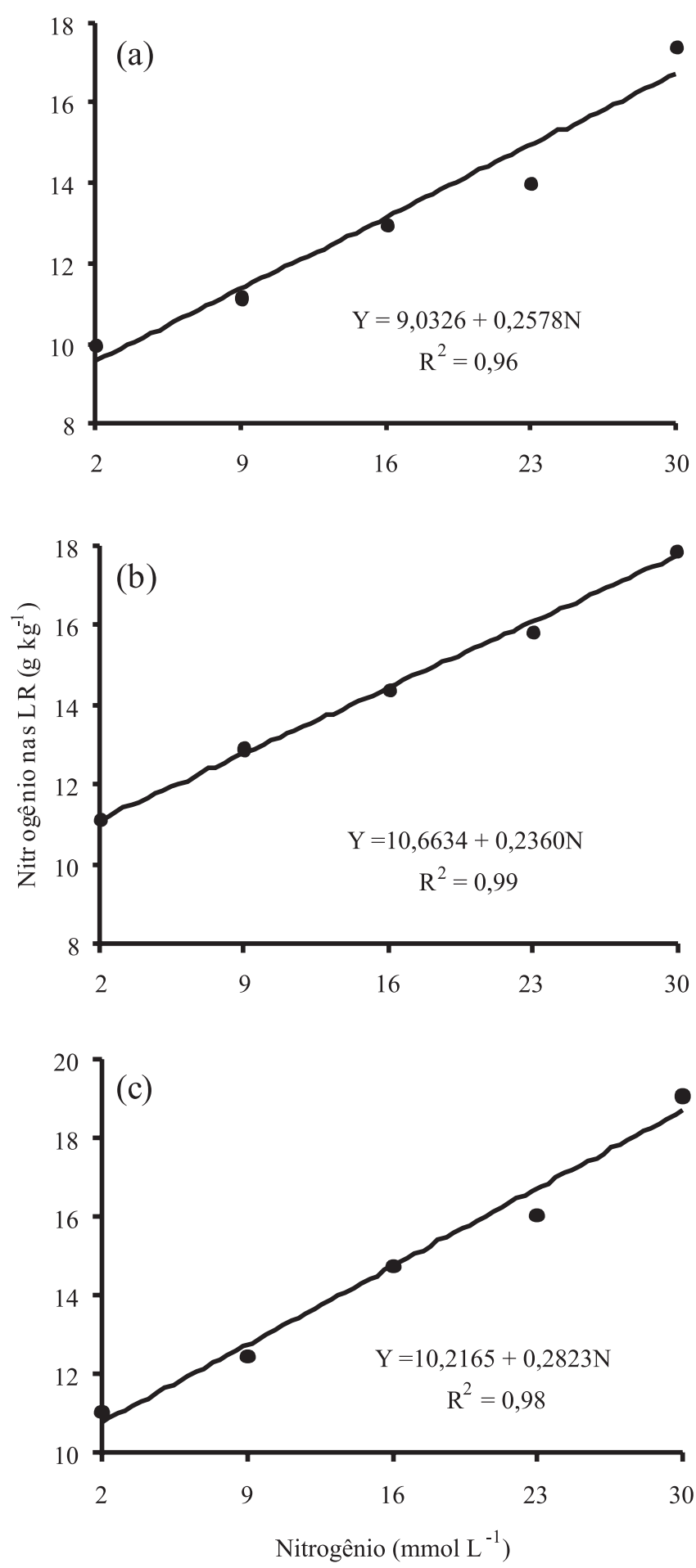

Figura 1 - Concentração de nitrogênio nas lâminas de folhas recém-expandidas (LR) no primeiro (a), segundo (b) e terceiro (c) cortes do capim-tanzânia adubado com nitrogênio.

recém-expandidas no primeiro corte do capim-braquiária variou de 12,2 a $30,0 \mathrm{~g} \mathrm{~kg}^{-1}$ entre a mais baixa e a mais elevada dose de nitrogênio.

A interação doses de nitrogênio $\times$ cálcio não foi significativa para a concentração de cálcio nas lâminas de 
folhas recém-expandidas colhidas no primeiro corte do capim-tanzânia. Entretanto, foi significativa para a concentração desse nutriente nas folhas no segundo e terceiro cortes do capim. No tecido vegetal coletado no primeiro corte, verificou-se efeito isolado das doses de cálcio na concentração desse nutriente nas lâminas de folhas recém-expandidas, com ajustes dos resultados ao modelo quadrático de regressão. A dose de cálcio que promoveria a concentração máxima desse mineral nas lâminas de folhas recém-expandidas do capim-tanzânia excederia a maior dose (5,5 mmol L $\left.{ }^{-1}\right)$ empregada neste experimento (Figura 2).

Lavres Jr. \& Monteiro (2002), estudando a concentração de cálcio nas lâminas de folhas recém-expandidas do capimmombaça submetido a combinações de nitrogênio e potássio, concluíram que as doses de nitrogênio não afetaram a concentração de cálcio nas folhas no primeiro corte do capim. No segundo crescimento do capim, no entanto, a concentração desse macronutriente reduziu diante das combinações de nitrogênio e potássio, como resultado do efeito competitivo do potássio na absorção de cálcio.

Santos Jr. (2005) observou concentrações máximas de cálcio nas lâminas de folhas recém-expandidas de capimtanzânia de $6,4 \mathrm{~g} \mathrm{~kg}^{-1}$ aos 26 dias de rebrotação no verão e de 4,1 a 6,4 g kg-1 para a rebrotação no ciclo de pastejo de outono. Avaliando a concentração de cálcio em lâminas de folhas recém-expandidas de capim-tanzânia em lotação contínua e em diversas alturas (24 a $78 \mathrm{~cm}$ ), Cecato et al. (2001) verificaram que a concentração média desse mineral nas lâminas foliares variou de 4,1 a 5,4 $\mathrm{g} \mathrm{kg}^{-1}$.

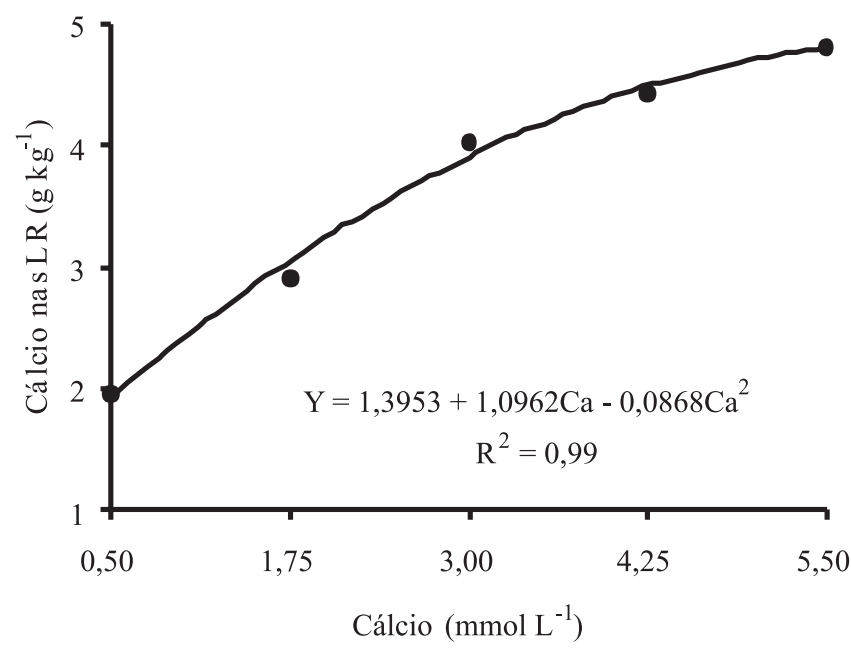

Figura 2 - Concentração de cálcio nas lâminas de folhas recémexpandidas (LR) coletadas no primeiro corte do capim-tanzânia adubado com cálcio.
No material coletado, tanto no segundo quanto no terceiro corte, a concentração de cálcio nas lâminas de folhas recém-expandidas ajustou-se ao modelo de regressão polinomial, em função das doses combinadas de nitrogênio e cálcio. As doses de nitrogênio de 12,8 e de 10,1 mmol L-1 corresponderam à mínima concentração de cálcio nas folhas do capim-tanzânia no segundo e terceiro cortes, respectivamente. A dose de cálcio de 4,8 mmol L-1 correspondeu à concentração máxima desse nutriente no segundo corte do capim, enquanto, no terceiro corte, a dose que corresponderia à concentração máxima de cálcio excedeu a maior dose de cálcio (5,5 $\left.\mathrm{mmol} \mathrm{L}^{-1}\right)$ empregada na solução nutritiva (Figura 3).

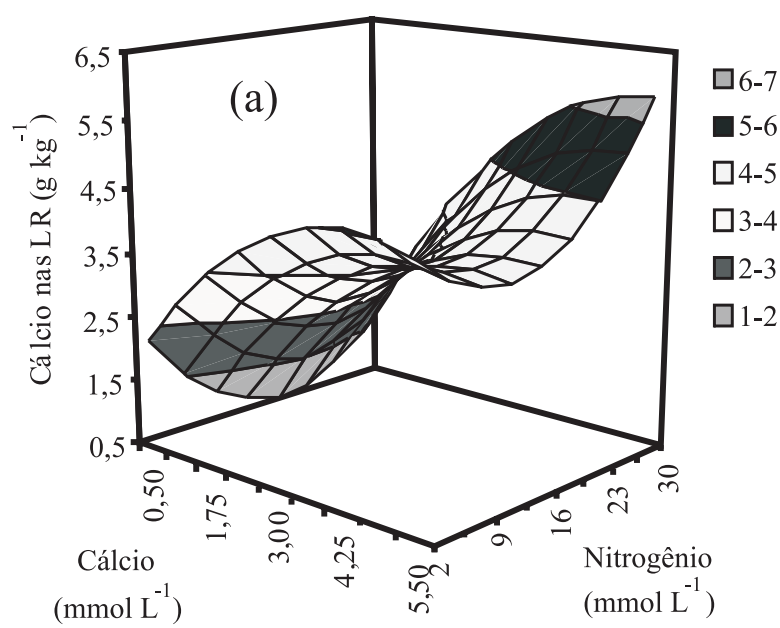

$\mathrm{Y}=1,9765-0,2384 \mathrm{~N}+0,0069 \mathrm{~N}^{2}+1,3599 \mathrm{Ca}-0,1585 \mathrm{Ca}^{2}+0,01292 \mathrm{NCa}$ $\mathrm{R}^{2}=0,78$

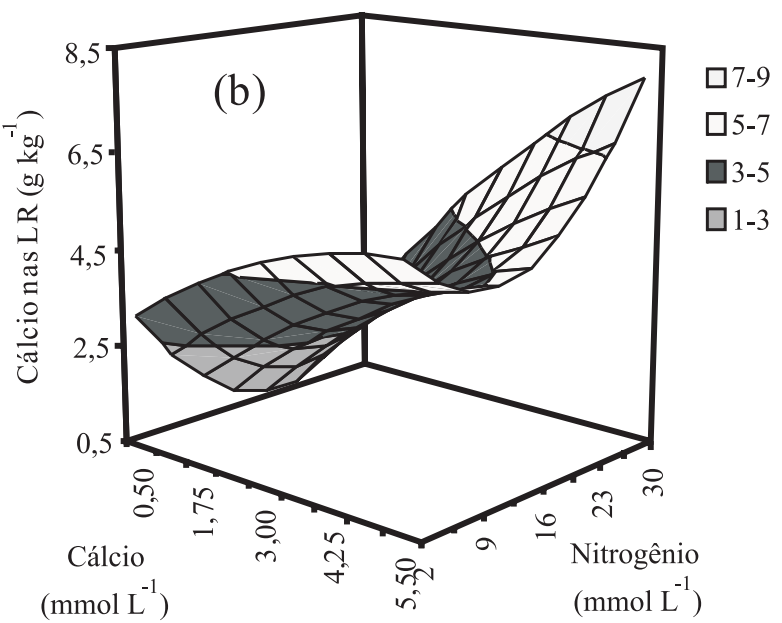
$\mathrm{Y}=3,4738-0,3705 \mathrm{~N}+0,01029 \mathrm{~N}^{2}+0,9029 \mathrm{Ca}-0,0796 \mathrm{Ca}^{2}+0,0231 \mathrm{NCa}$
$\mathrm{R}^{2}=0,63$

Figura 3 - Concentração de cálcio em lâminas de folhas recémexpandidas (LR) coletadas no segundo (a) e terceiro (b) cortes do capim-tanzânia adubado com nitrogênio e cálcio. 
Colozza (1998), em experimento sobre o rendimento e a diagnose foliar de Panicum maximum, cultivares Aruana e Mombaça, verificou efeito positivo das doses de nitrogênio na concentração de cálcio nas lâminas de folhas recém-expandidas e atribuiu esse fato ao aumento da concentração de nitrato nas plantas, que aumenta a absorção de cátions para manutenção do balanço de cátions-ânions na planta (Mengel \& Kirkby, 2001).

Avaliando o capim-tanzânia submetido às proporções de nitrato e amônio na solução nutritiva, Abreu (1994) descreveu que o fornecimento de nitrogênio 100\% na forma de nitrato na solução não afetou significativamente a concentração de cálcio na parte aérea e que, nas lâminas de folhas recém-expandidas, a concentração de cálcio foi de $2,1 \mathrm{~g} \mathrm{~kg}^{-1}$ quando se forneceu cálcio e de $1,0 \mathrm{~g} \mathrm{~kg}^{-1} \mathrm{na}$ ausência desse nutriente na solução com $75 \%$ nitrato e 25\% amônio.

As lâminas de folhas recém-expandidas refletiram diretamente a diferença na disponibilidade de nitrogênio e cálcio (Figuras 1, 2 e 3), confirmando que realmente essas lâminas foliares são as mais recomendadas para a avaliação do estado nutricional desse capim.

A interação doses de nitrogênio $\times$ cálcio não foi significativa para a concentração de fósforo nas lâminas de folhas recém-expandidas em qualquer dos cortes do capimtanzânia. Apenas as doses de nitrogênio alteraram a concentração de fósforo nas lâminas de folhas recémexpandidas nas três coletas de tecidos foliares (Figura 4).

O decréscimo na concentração de fósforo nas lâminas de folhas recém-expandidas do capim-tanzânia pode ter sido ocasionado pela diluição do nutriente na planta, decorrente do aumento de produção de massa seca da parte aérea com o aumento das doses de nitrogênio fornecidas na solução nutritiva. Esse fato já foi demonstrado para Panicum maximum, em capim-colonião (Mattos \& Werner, 1979), nos capins aruana e mombaça (Colozza, 1998) e em capim-tanzânia (Santos Jr., 2005).

Trabalhando com o capim-tanzânia sob lotação contínua e diversas alturas de corte, Cecato et al. (2001) demonstraram que a concentração de fósforo nas lâminas foliares variaram de 4,2 a 4,9 $\mathrm{g} \mathrm{kg}^{-1}$ ao longo do período experimental. Aguiar (2004), em estudo das concentrações de nutrientes em partes do capim-tanzânia irrigado, observou variação de 2,0 a 3,0 $\mathrm{g} \mathrm{kg}^{-1}$ na concentração de fósforo nas lâminas de folhas recém-expandidas entre os períodos de coleta e as intensidades de pastejo.

Para a concentração de potássio nas lâminas foliares recém-expandidas amostradas nos três cortes do capimtanzânia, a combinação de nitrogênio $\times$ cálcio não foi significativa. Na concentração de potássio nessas folhas coletadas no primeiro corte, as doses de nitrogênio e de cálcio, isoladamente, não tiveram efeito significativo. Nessas lâminas foliares amostradas no segundo e terceiro cortes, apenas as doses de nitrogênio influenciaram a concentração de potássio (Figura 5).
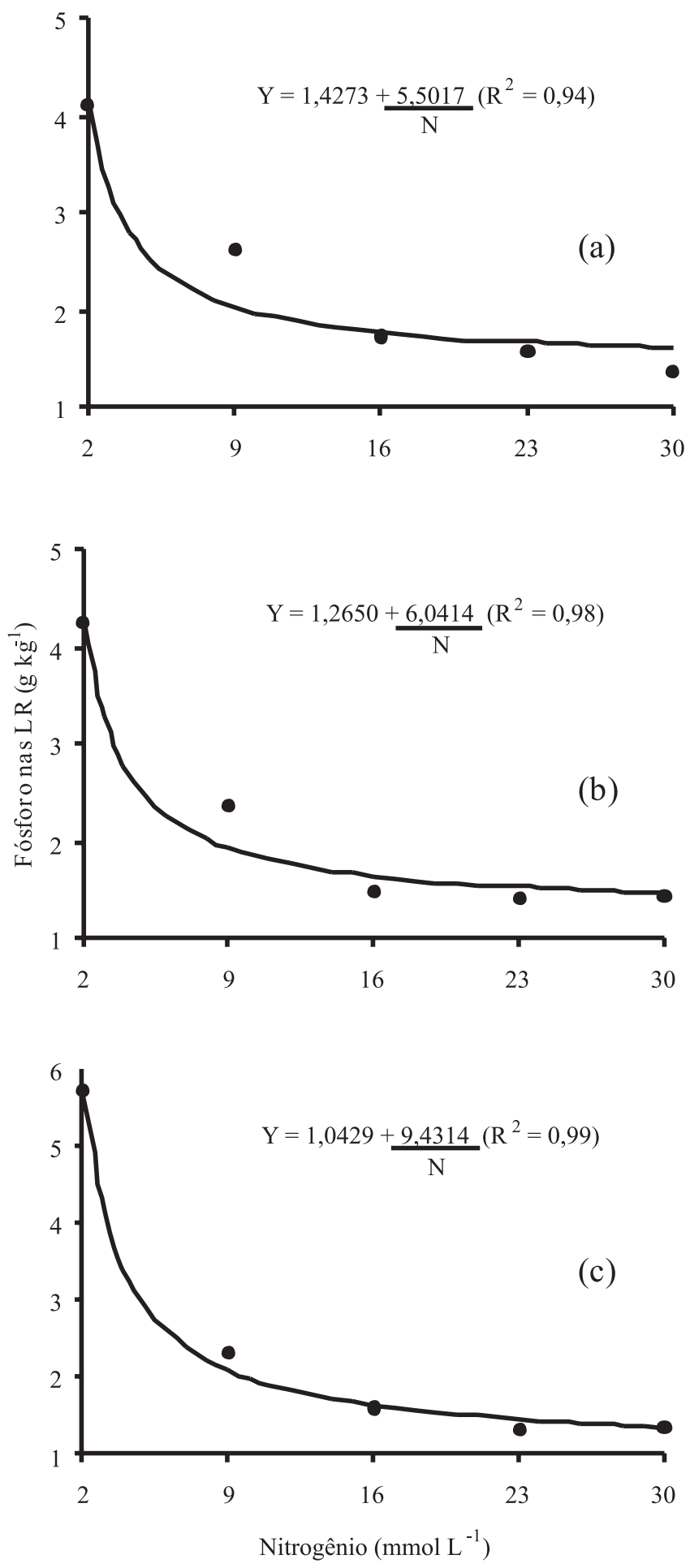

Figura 4 - Concentração de fósforo nas lâminas de folhas recémexpandidas (LR) coletadas no primeiro (a), segundo (b) e terceiro (c) cortes do capim-tanzânia adubado com nitrogênio. 


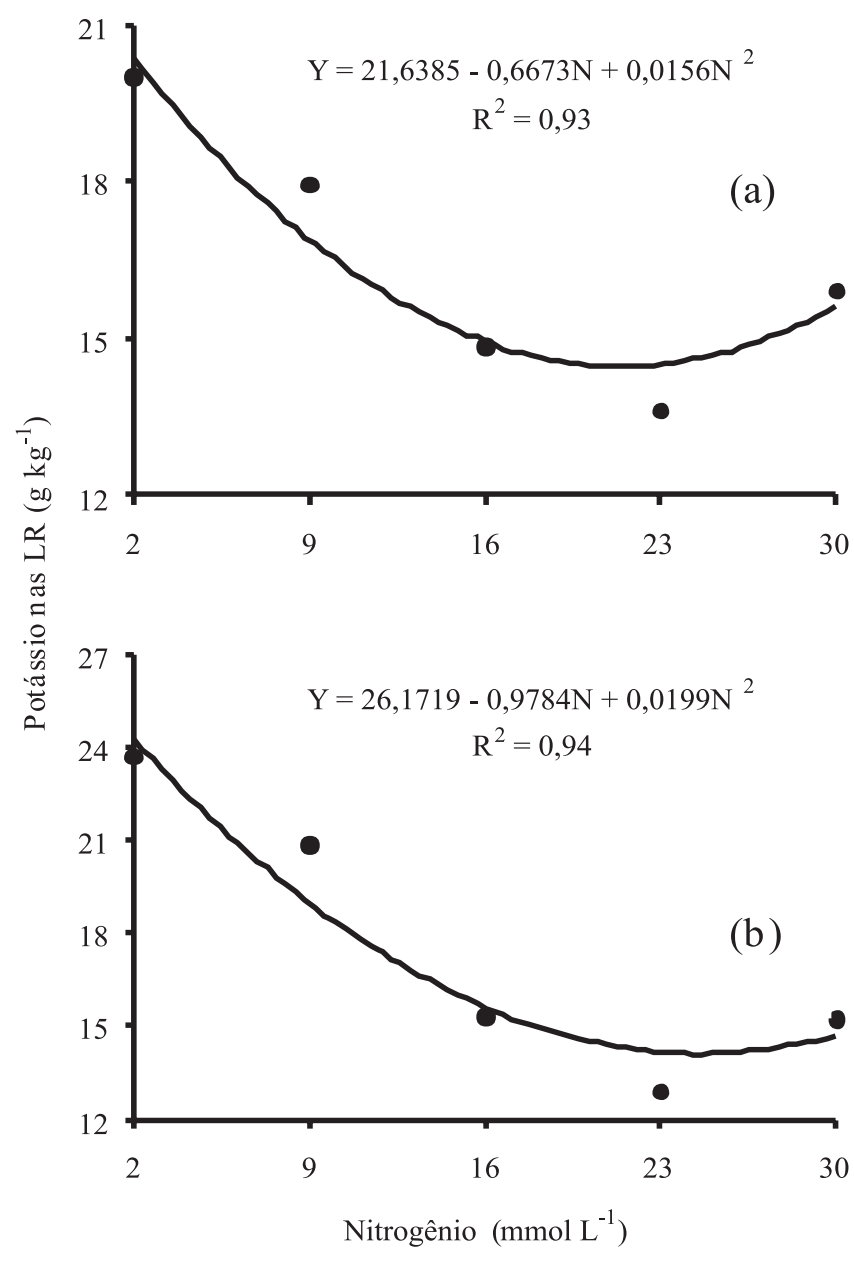

Figura 5 - Concentração de potássio nas lâminas de folhas recémexpandidas (LR) coletadas no segundo (a) e terceiro (b) cortes do capim-tanzânia adubado com nitrogênio.

No segundo e terceiro cortes do capim-tanzânia, a concentração de potássio nas lâminas de folhas recémexpandidas sofreu variação segundo modelo quadrático de regressão com as doses de nitrogênio. A concentração mínima de potássio $\left(14,5 \mathrm{~g} \mathrm{~kg}^{-1}\right)$ foi obtida com a dose de nitrogênio de $21,4 \mathrm{mmol} \mathrm{L}^{-1}$ no tecido amostrado no segundo corte (Figura 5a), enquanto, no terceiro corte das plantas, a mais baixa concentração de potássio (14,2 $\left.\mathrm{g} \mathrm{kg}^{-1}\right)$ foi obtida na dose de nitrogênio de 24,6 $\mathrm{mmol} \mathrm{L}^{-1}$ (Figura 5b).

As concentrações mínimas de potássio (14,2 e $14,5 \mathrm{~g} \mathrm{~kg}^{-1}$ ) nas lâminas de folhas recém-expandidas, tanto no segundo quanto no terceiro corte, foram superiores ao nível crítico de $13,0 \mathrm{~g} \mathrm{~kg}^{-1}$ estabelecido por Mattos et al. (2002) para as folhas emergentes + lâminas de folhas recém-expandidas do capim-tanzânia. A concentração de potássio de $8,0 \mathrm{mmol} \mathrm{L}^{-1}$ fornecida na solução nutritiva, mais elevada que a recomendada por Sarruge (1975), foi suficiente para atender à demanda de potássio, mesmo em caso de elevadas doses de nitrogênio após o primeiro período de crescimento.

Ferragine (1998) observou efeitos negativos do nitrogênio na concentração de potássio nas lâminas foliares recém-expandidas coletadas no primeiro e segundo cortes do capim-braquiária e que a dose que corresponderia à mínima concentração de potássio nesse tecido seria superior à maior dose de nitrogênio $\left(31,0 \mathrm{mmol} \mathrm{L}^{-1}\right)$ fornecida na solução nutritiva.

A variação na concentração de potássio nas lâminas de folhas recém-expandidas foi de 15,6 a 20,4 $\mathrm{g} \mathrm{kg}^{-1}$ no segundo corte (Figura 5a) e de 14,2 a 24,3 $\mathrm{g} \mathrm{kg}^{-1}$ no terceiro corte (Figura $5 b$ ). Essas concentrações de potássio nesse capim são inferiores às de 31,0 a $22,8 \mathrm{~g} \mathrm{~kg}^{-1}$ obtidas por Santos Jr. (2005) e de 28,8 a $24,6 \mathrm{~g} \mathrm{~kg}^{-1}$ encontradas por Aguiar (2004).

O aumento na quantidade absorvida de um cátion na planta comumente diminui a absorção de outros cátions (Marschner, 1995). Neste trabalho não se verificou efeito negativo das doses de cálcio na absorção de potássio e o suprimento de potássio $\left(8,0 \mathrm{mmol} \mathrm{L}^{-1}\right)$ foi mais elevado que o de cálcio (máximo de $5,5 \mathrm{mmol} \mathrm{L}^{-1}$ ), como também

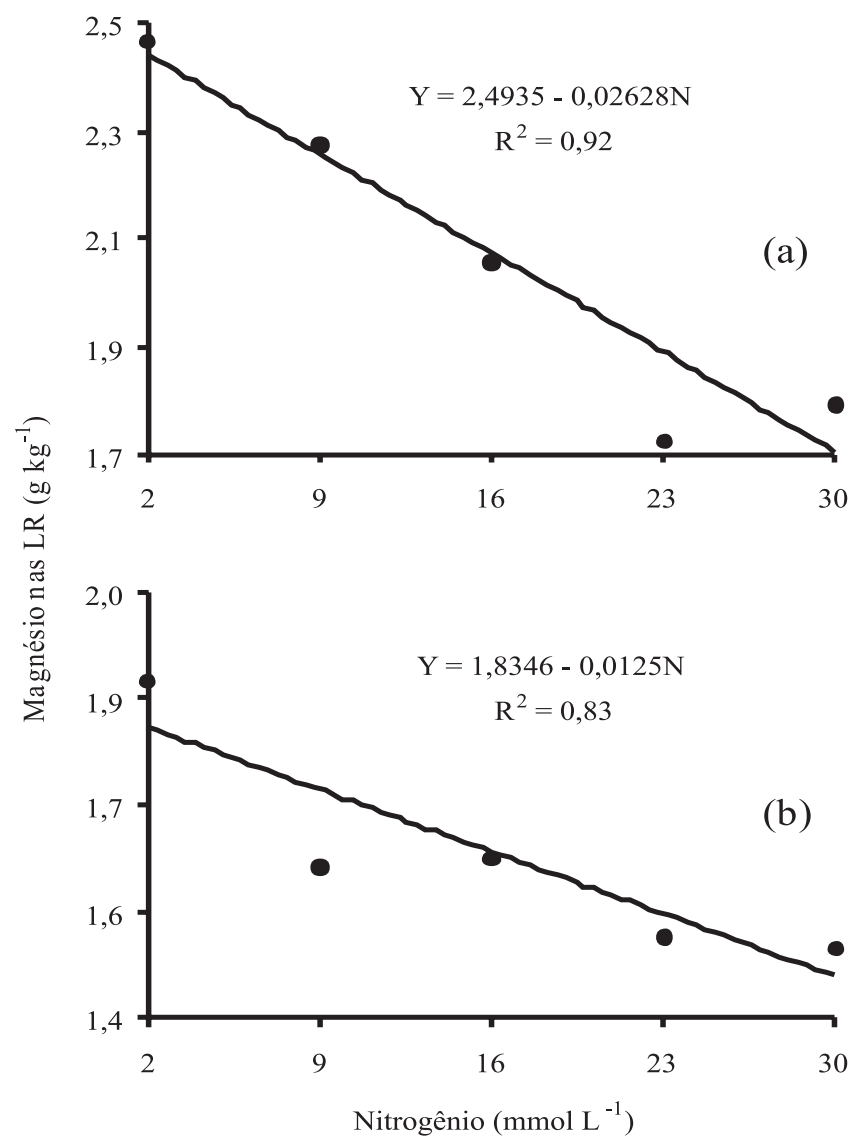

Figura 6 - Concentração de magnésio nas lâminas de folhas recémexpandidas (LR) coletadas no primeiro (a) e segundo (b) cortes do capim-tanzânia adubado com nitrogênio. 
ocorre na solução de Sarruge (potássio, 6,0 mmol L-1 e cálcio, 5,0 mmol L ${ }^{-1}$ ). Redução na concentração de potássio na parte aérea do capim-braquiária foi observada por Vitor et al. (2008), que, ao avaliarem a composição química desse capim nos períodos seco e chuvoso, atribuíram esse resultado à diluição do nutriente com o aumento da produção de massa seca.
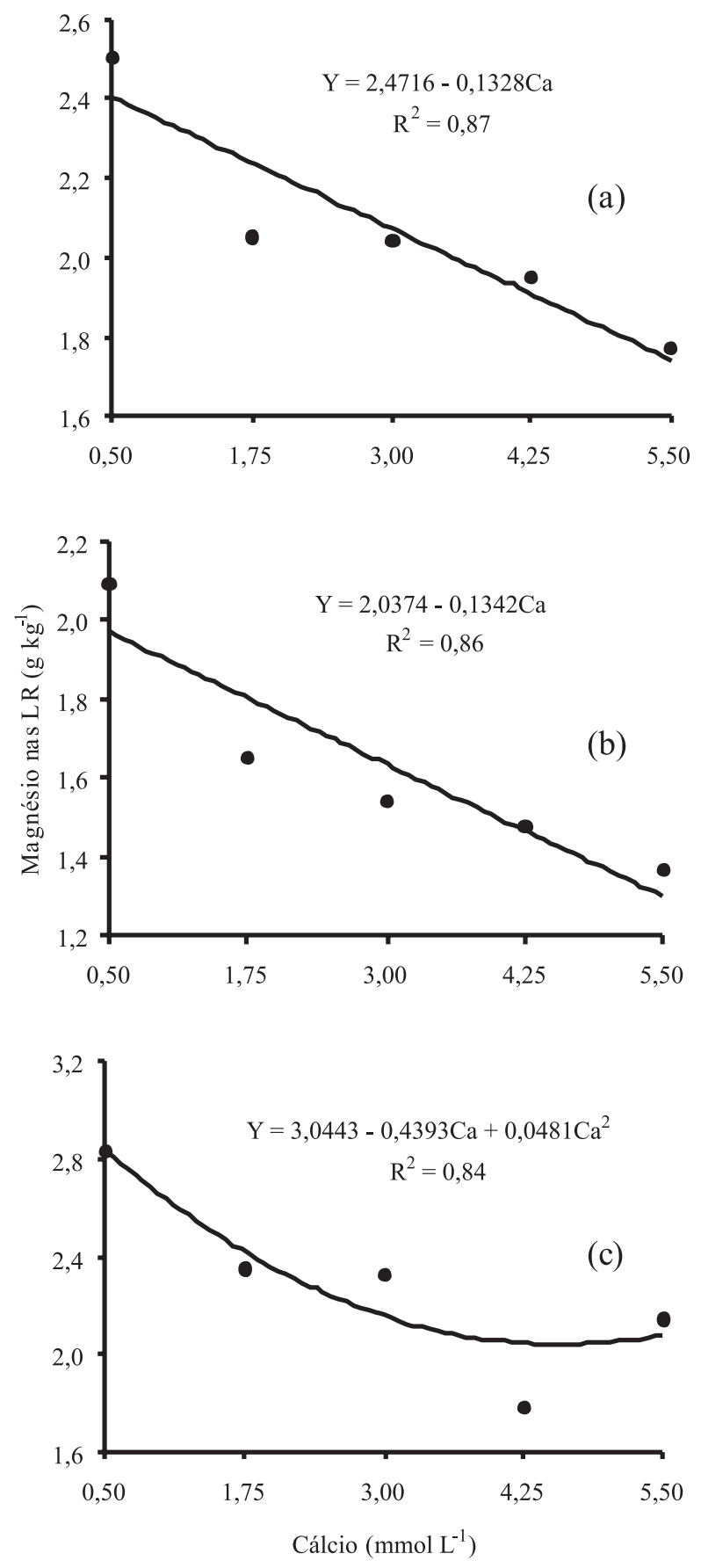

Figura 7 - Concentração de magnésio nas lâminas de folhas recémexpandidas (LR) coletadas no primeiro (a), segundo (b) e terceiro (c) cortes do capim-tanzânia adubado com cálcio.
A combinação nitrogênio $\times$ cálcio não influenciou a concentração de magnésio nas lâminas de folhas recémexpandidas coletadas nos três cortes do capim-tanzânia. Efeitos negativos das doses de nitrogênio e cálcio foram observados, com ajuste dos resultados ao modelo linear de regressão, tanto no primeiro como no segundo corte das plantas (Figuras 6 e 7). No terceiro corte, esses efeitos negativos foram constatados para as doses de cálcio, com resultados que se ajustaram ao modelo quadrático de regressão (Figura 7).

A concentração de magnésio decresceu de forma linear com o suprimento de nitrogênio na solução nutritiva, variando de 2,5 a $1,7 \mathrm{~g} \mathrm{~kg}^{-1}$ no primeiro corte (Figura 6a) e de 1,9 a $1,5 \mathrm{~g} \mathrm{~kg}^{-1}$ no segundo corte (Figura $6 \mathrm{~b}$ ), fato atribuído ao efeito de diluição e à presença do íon amônio na solução nutritiva, o qual pode reduzir a absorção desse mineral pelo capim (Tisdale et al., 1985).

A inibição competitiva também pode ter ocorrido com o potássio influenciando a absorção do magnésio e sua concentração nas folhas do capim, em decorrência do fornecimento de potássio em dose mais elevada que a da solução de Sarruge (1975). Mattos et al. (2002) verificaram, em dois cortes do capim-tanzânia, que a concentração de magnésio nas folhas emergentes + lâminas de folhas recémexpandidas reduziu significativamente, como consequência do aumento no suprimento de magnésio na solução nutritiva.

Santos Jr. (2005), avaliando a concentração de macronutrientes nas lâminas de folhas recém-expandidas do capim-tanzânia em dois ciclos de pastejo, verificou que a concentração máxima de magnésio foi de $3,9 \mathrm{~g} \mathrm{~kg}^{-1}$ no ciclo de pastejo de verão e que, no ciclo no outono, a concentração desse mineral variou de 3,0 a $3,3 \mathrm{~g} \mathrm{~kg}^{-1}$. Para o mesmo capim, Aguiar (2004) encontrou variação na concentração de potássio de 3,4 a 4,8 $\mathrm{g} \mathrm{kg}^{-1}$ nas folhas.

Efeito negativo das doses de nitrogênio na concentração de magnésio nas lâminas de folhas recémexpandidas, com ajuste ao modelo linear de regressão, também foi observado por Ferragine (1998) no primeiro corte do capim-braquiária. No segundo corte, verificou significância para a combinação de nitrogênio e potássio na concentração de magnésio nas lâminas de folhas recémexpandidas, com ajuste dos resultados ao modelo quadrático de regressão.

Com o fornecimento de cálcio na solução nutritiva, a concentração de magnésio nas lâminas de folhas recémexpandidas do capim-tanzânia ajustou-se ao modelo de primeiro grau, com variação de 1,8 a $2,5 \mathrm{~g} \mathrm{~kg}^{-1}$ nos resultados na amostragem do primeiro corte (Figura 7a) e de 1,4 a 2,1 $\mathrm{g} \mathrm{kg}^{-1}$ naquela do segundo corte (Figura 7b). No terceiro corte do capim-tanzânia, a dose de cálcio de 
4,6 mmol $\mathrm{L}^{-1}$ resultou na mais baixa concentração de magnésio nas folhas $\left(2,1 \mathrm{~g} \mathrm{~kg}^{-1}\right)$, evidenciando o efeito negativo do suprimento de cálcio na aquisição de magnésio pelo capim-tanzânia (Figura 7c). Esse efeito negativo das doses de cálcio deve-se à interferência da absorção desse mineral na absorção do magnésio, pela inibição competitiva entre ambos os cátions.

Nogueira et al. (1997) verificaram reduções na concentração de magnésio em folhas do capim-napier (Pennisetum purpureum cv. Napier), devido ao aumento excessivo de cálcio no solo. Constataram que, quanto maior a relação cálcio/magnésio no solo, mais baixa a concentração de magnésio na planta, o que evidencia a interferência do cálcio na absorção de magnésio.

O aumento da concentração de cálcio na solução nutritiva, que se mostrou desnecessário em termos de produção de massa seca, área foliar e número de perfilhos e folhas (Silveira \& Monteiro, 2007), ocasionou severa redução na concentração de magnésio nas lâminas de folhas recém-expandidas do capim-tanzânia. No material amostrado em todos os cortes do capim-tanzânia, a concentração de magnésio esteve abaixo do nível crítico encontrado no capim-mombaça $\left(4,2 \mathrm{~g} \mathrm{~kg}^{-1}\right)$ e a adição de doses mais elevadas de cálcio inibiu competitivamente a absorção de magnésio pelo capim.

As doses de nitrogênio e cálcio, quando combinadas na solução nutritiva, influenciaram a concentração de enxofre nas lâminas de folhas recém-expandidas coletadas nos três cortes do capim-tanzânia (Figura 8). As folhas das plantas, no primeiro corte, mostraram variação de 0,3 a $2,2 \mathrm{~g} \mathrm{~kg}^{-1}$ na concentração de enxofre. A mais baixa concentração desse mineral foi obtida na dose de nitrogênio de 2,0 mmol L-1 combinada com cálcio de 3,0 mmol L-1, enquanto a mais alta foi verificada com a combinação da mais alta dose de nitrogênio $\left(30,0 \mathrm{mmol} \mathrm{L}^{-1}\right)$ com a mais baixa de cálcio $\left(0,5 \mathrm{mmol} \mathrm{L}^{-1}\right)$ (Figura $8 \mathrm{a}$ ).

No segundo corte do capim-tanzânia, a concentração de enxofre nas lâminas de folhas recém-expandidas variou de 0,7 a $1,8 \mathrm{~g} \mathrm{~kg}^{-1}$ e foi mais alta quando combinada a mais alta dose de nitrogêno com a dose mais baixa de cálcio (Figura 8b). No terceiro corte das plantas, a mais alta concentração de enxofre nas folhas também foi verificada na combinação da mais alta dose de nitrogênio com a mais baixa de cálcio, com variação de 1,0 a 2,6 g kg-1 na concentração de enxofre no tecido vegetal (Figura 8c).

Monteiro et al. (1995) relataram que a ausência de cálcio na solução nutritiva aumentou a concentração de enxofre na parte aérea do capim-marandu, uma vez que, quando aplicada a solução completa, a concentração de enxofre foi de 1,9 $\mathrm{g} \mathrm{kg}^{-1}$, enquanto, na ausência de cálcio, foi de
$2,5 \mathrm{~g} \mathrm{~kg}^{-1}$. Esse resultado deve-se ao fato de o nitrogênio ter sido totalmente fornecido como nitrato $\left(\mathrm{NO}_{3}{ }^{-}\right)$na solução completa, enquanto, na ausência de cálcio, o nitrogênio foi, em parte, fornecido como amônio $\left(\mathrm{NH}_{4}^{+}\right)$e,
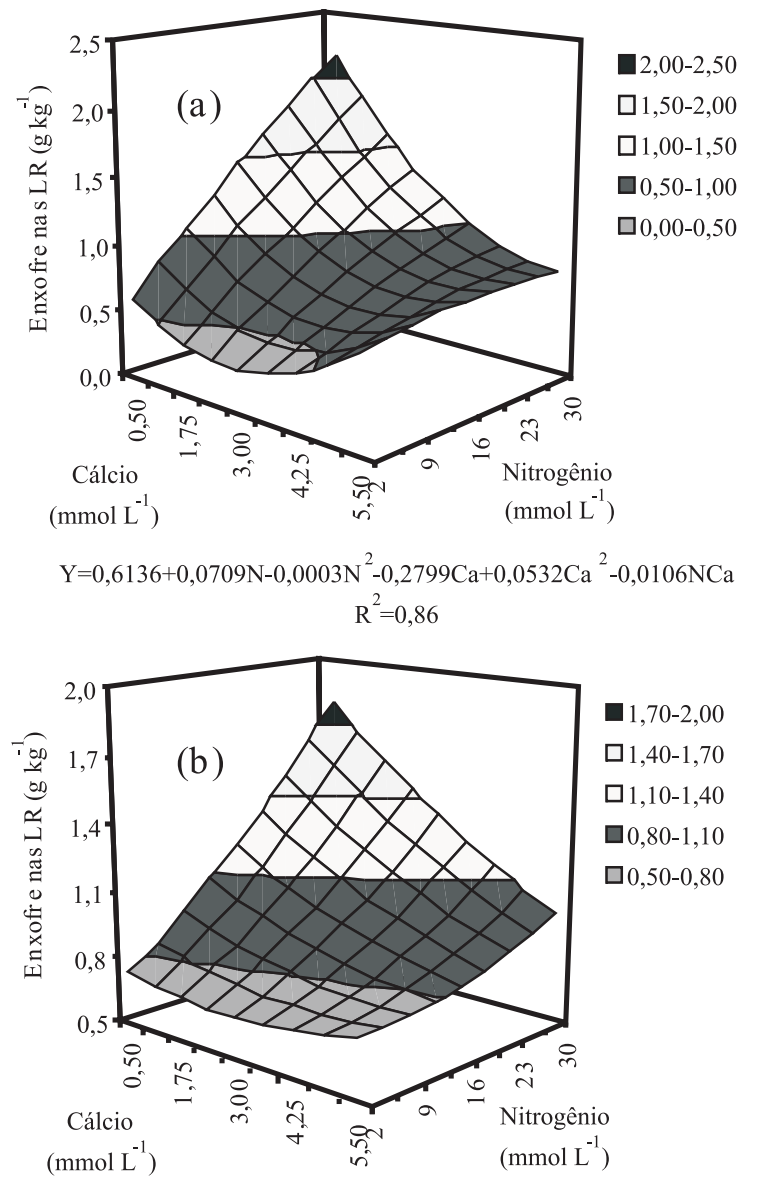

$\mathrm{Y}=0,7028+0,0298 \mathrm{~N}-0,0003 \mathrm{~N}^{2}-0,0393 \mathrm{Ca}+0,0094 \mathrm{Ca}^{2}-0,0059 \mathrm{NCa}$ $\mathrm{R}^{2}=0,77$

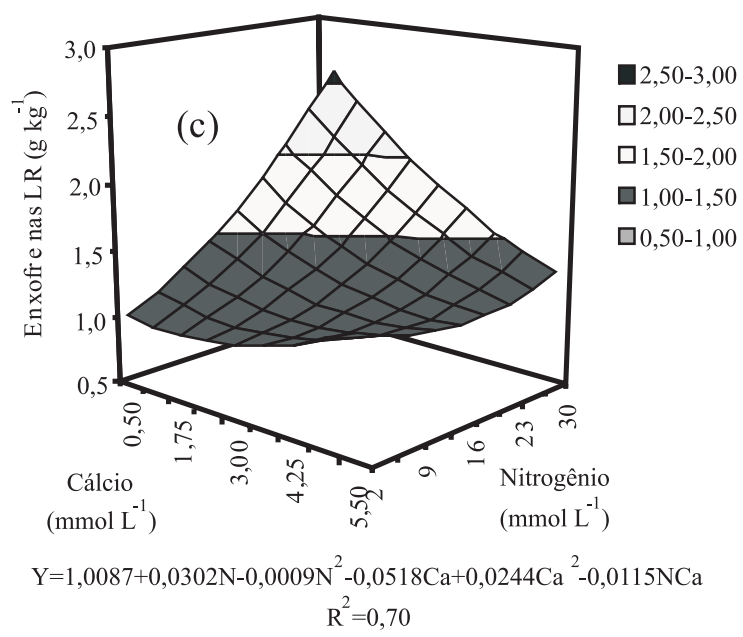

Figura 8 - Concentração de enxofre em lâminas de folhas recémexpandidas (LR) coletadas no primeiro (a), segundo (b) e terceiro (c) cortes do capim-tanzânia adubado com nitrogênio e cálcio. 
segundo Tisdale et al. (1985), a absorção de nitrogênio na forma amoniacal pode estimular a absorção de enxofre.

Lavres Jr. \& Monteiro (2002) comprovaram que as concentrações de enxofre nas lâminas de folhas recémexpandidas variaram de 1,6 a 2,1 $\mathrm{g} \mathrm{kg}^{-1}$, respectivamente, na combinação das mais baixas para as mais altas doses de nitrogênio e potássio na amostragem do primeiro corte e de 1,3 a $1,8 \mathrm{~g} \mathrm{~kg}^{-1}$ naquela do segundo corte do capimmombaça, quando forneceram enxofre na solução nutritiva em concentração igual à utilizada neste experimento $\left(2,0 \mathrm{mmol} \mathrm{L}^{-1}\right)$.

Avaliando a combinação de nitrogênio e enxofre para o capim-marandu, Batista \& Monteiro (2007) constataram que a mais elevada concentração de enxofre nas lâminas recém-expandidas colhidas por ocasião do primeiro corte correspondeu à dose de nitrogênio de $33,0 \mathrm{mmol} \mathrm{L}^{-1}$, associada a qualquer dose de enxofre. Na amostragem do segundo corte, a concentração mais elevada de enxofre nas lâminas de folhas recém-expandidas foi encontrada nas combinações de altas doses, tanto de nitrogênio como de enxofre.

Variação da concentração de enxofre nas lâminas de folhas recém-expandidas de 1,2 a $1,5 \mathrm{~g} \mathrm{~kg}^{-1}$ no capimtanzânia foi encontrada por Aguiar (2004) em estudo de períodos de coleta e intensidade de pastejo. Para o mesmo capim, Santos Jr. (2005) verificou variação de 1,3 a $1,8 \mathrm{~g} \mathrm{~kg}^{-1}$ e de 1,5 a $2,0 \mathrm{~g} \mathrm{~kg}^{-1}$ nos ciclos de pastejo de verão e de outono, respectivamente.

\section{Conclusões}

A combinação de cálcio e nitrogênio na solução nutritiva influencia a concentração de enxofre nas folhas de capimtanzânia nos três cortes e a concentração de cálcio no segundo e terceiro cortes do capim. As concentrações de nitrogênio, fósforo e potássio nas folhas dependem do suprimento de nitrogênio, e não de cálcio. As doses de cálcio, isoladamente, são determinantes, no primeiro crescimento, da concentração desse nutriente nas lâminas foliares do capim. A concentração de magnésio nas folhas reduz com o aumento do suprimento, tanto de nitrogênio quanto de cálcio. A utilização de dose de cálcio correspondente a $40 \%$ daquela empregada na solução nutritiva não restringe os parâmetros nutricionais desse capim, mesmo na presença de elevadas doses de nitrogênio.

\section{Referências}

ABREU, J.B.R. Níveis de nitrogênio e proporções de nitrato e amônio afetando produção, atividade da redutase do nitrato e composição de três gramíneas forrageiras. 1994. 109f. Dissertação (Mestrado em Solos e Nutrição de Plantas) Escola Superior de Agricultura "Luiz de Queiroz", Piracicaba.

AGUIAR, R.N.S. Avaliação de parâmetros minerais e determinação das normas DRIS do capim-Tanzânia. 2004. 148f. Dissertação (Mestrado em Ciência Animal e Pastagem) Escola Superior de Agricultura "Luiz de Queiroz”, Piracicaba.

BATISTA, K.; MONTEIRO, F.A. Nitrogen and sulphur in Marandu grass: relationship between supply and concentration in leaf tissues. Scientia Agrícola, v.64, n.1, p.44-51, 2007.

CARVALHO, M.M.; MARTINS, C.E.; VERNEQUE, R.S. et al. Respostas de uma espécie de Brachiaria à fertilização com nitrogênio e potássio em um solo ácido. Revista Brasileira de Ciência do Solo, v.15, n.1, p.195-200, 1991.

CECATO, U.; RÊGO, F.C.A.; CANTO, M.W. et al. Conteúdo de minerais do capim-Tanzânia manejado em diferentes alturas, sob pastejo. In: REUNIÃO ANUAL DA SOCIEDADE BRASILEIRA DE ZOOTECNIA, 38., 2001, Piracicaba. Anais... Piracicaba: Sociedade Brazileira de Zootecnia, 2001. p.120-121.

COLOZZA, M.T. Rendimento e diagnose foliar dos capins Aruana e Mombaça cultivados em Latossolo VermelhoAmarelo. 1998. 127f. Tese (Doutorado em Solos e Nutrição de Plantas) - Escola Superior de Agricultura "Luiz de Queiroz", Piracicaba.

FERRAGINE, M.C. Combinações de doses de nitrogênio e potássio na nutrição mineral de capim-braquiária. 1998. 84f. Dissertação (Mestrado em Solos e Nutrição de Plantas) Escola Superior de Agricultura "Luiz de Queiroz", Piracicaba.

LAVRES JR., J.; MONTEIRO, F.A. Combinações de doses de nitrogênio e potássio para a produção e nutrição do capim-Mombaça. Boletim de Indústria Animal, v.59, n.1, p.102-114, 2002.

LITTELL, R.C.; MOTT, G.O. Computer assisted design and analysis of response surface experiments in agronomy. Soil and Crop Society of Florida Proceedings, v.34, n.5, p.94-97, 1975.

MACEDO, M.C.M. Análise comparativa de recomendações de adubação em pastagem. In: SIMPÓSIO SOBRE MANEJO DA PASTAGEM, 21., 2004, Piracicaba. Anais... Piracicaba: Fundação de Estudos Agrários Luiz de Queiroz, 2004. p.317-355.

MANARIN, C.A.; MONTEIRO, F.A. Nitrogênio na produção e diagnose foliar do capim-Mombaça. Boletim de Indústria Animal, v.59, n.2, p.115-123, 2002.

MARSCHNER, H. Mineral nutrition of higher plants. 2.ed. London: Academic Press, 1995. 889p.

MATTOS, H.B.; WERNER, J.C. Efeitos de nitrogênio mineral e de leguminosas sobre a produção de capim-Colonião (Panicum maximum Jacq.). Boletim de Indústria Animal, v.36, n.1, p.147-156, 1979.

MATTOS, W.T.; MONTEIRO, F.A. Produção e nutrição de capimBraquiária em função de doses de nitrogênio e enxofre. Boletim de Indústria Animal, v.60, n.1, p.1-10, 2003.

MATTOS, W.T.; SANTOS, A.R.; ALMEIDA, A.A.S. et al. Aspectos produtivos e diagnose nutricional do capim-Tanzânia submetido a doses de potássio. Magistra, v.14, n.1, p.37-44, 2002.

MENGEL, K.; KIRKBY, E.A. Principles of plant nutrition. Dordrechth: Kluwer Academic Publishers, 2001. 849p.

MONTEIRO, F.A.; BENETTI, I.; CARMELLO, Q.A.C. Tanzânia grass: nitrogen distribution in shoots and utilization. In: HORST, W.J.; SCHENK, M.K.; BÜRKERT, A. et al. (Eds.) Plant nutrition: food security and sustainability of agro-ecosystems. Netherlands, 2001. p.802-803.

MONTEIRO, F.A.; RAMOS, A.K.B.; CARVALHO, D.D. et al. Cultivo de Brachiaria brizantha Stapf. cv. Marandu em solução nutritiva com omissões de macronutrientes. Scientia Agrícola, v.52, n.1, p.135-141, 1995.

MONTEIRO, F.A.; WERNER, J.C. Efeitos das adubações nitrogenada e fosfatada em capim-Colonião, na formação e em pasto estabelecido. Boletim de Indústria Animal, v.34, n.1, p.91-101, 1977. 
NOGUEIRA, A.; PAULA, M.B.; CARVALHO, J.G. et al. Efeito de diferentes relações $\mathrm{Ca}: \mathrm{Mg}$ do corretivo no crescimento de capim Napier. In: CONGRESSO BRASILEIRO DE CIÊNCIA DO SOLO, 26., 1997, Rio de Janeiro. Anais... Rio de Janeiro: Sociedade Brasileira de Ciência do Solo, [1997]. (CD-ROM).

SANTOS JR., J.D.G. Fertilidade do solo no acúmulo de forragem e nutrição do capim-Tanzânia sob pastejo na região dos Cerrados. 2005. 105f. Tese (Doutorado em Solos e Nutrição de Plantas) - Escola Superior de Agricultura "Luiz de Queiroz”, Piracicaba.

SARRUGE, J.R. Soluções nutritivas. Summa Phytopathologica, v.1, n.3, p.231-233, 1975.

SARRUGE, J.R.; HAAG, H.P. Análises químicas em plantas. Piracicaba: Escola Superior de Agricultura “Luiz de Queiroz”, 1974. 56p.
SILVEIRA, C.; MONTEIRO, F.A. Morfogênese e produção de biomassa do capim-tanzânia adubado com nitrogênio e cálcio. Revista Brasileira de Zootecnia, v.36, n.2, p.335-342, 2007. STATISTICAL ANALYSIS SYSTEM - SAS. User's guide statistics. version 8.0. Cary: SAS Institute, 1999. 956p.

TISDALE, S.L.; BEATON, J.D.; NELSON, W.L. Soil fertility and fertilizers. 4.ed. New York: Mac Millan, 1985. 754p.

VITOR, C.M.T.; FONSECA, D.M.; MOREIRA, L.M. et al. Rendimento e composição química do capim-braquiária introduzido em pastagem degradada de capim-gordura. Revista Brasileira de Zootecnia, v.37, n.12, p.2107-2114, 2008.

VOLPE, E.; MARCHETTI, M.E.; MACEDO, M.C.M. et al. Acúmulo de forragem e características do solo e da planta no estabelecimento de capim-massai com diferentes níveis de saturação por bases, fósforo e nitrogênio. Revista Brasileira de Zootecnia, v.37, n.2, p.228-237, 2008. 